\title{
PENGEMBANGAN BUKU BERGAMBAR PADA TEMA DIRIKU UNTUK MENINGKATKAN KETERAMPILAN BERBICARA SISWA KELAS I SD GUGUS 2 KECAMATAN PENEBELTABANAN
}

\author{
L.A. Parwati ${ }^{1}$, I.B. Putrayasa ${ }^{2}$, I.W. Suastra ${ }^{3}$ \\ ${ }^{123}$ Program Studi Pendidikan Dasar \\ Universitas Pendidikan Ganesha \\ Denpasar, Indonesia \\ e-mail: ari.parwati@undiksha.ac.id ${ }^{1}$, ibputra@gmail.com ${ }^{2}$, \\ iwsuastra@undiksha.ac.id ${ }^{3}$
}

\begin{abstract}
Abstrak
Penelitian ini bertujuan untuk mengembangkan dan menghasilkan produk berupa buku bergambar Tema Diriku Untuk Meningkatkan Keterampilan Berbicara Siswa kelas I SD dan buku panduan gurunya .Jenis penelitian ini adalah penelitian pengembangan desain dan produk (Design and Development) dengan merujuk pada model ADDIE (Analysis, Design, Development, Implementatian, Evaluation). Data yang dikumpulkan berupa data validitas dan kepraktisan. Instrumen penelitian yang digunakan yaitu: lembar validasi dan angket. Lembar validasi dipakai untuk mengumpulkan data tentang validitas buku. Angket respon digunakan untuk mengumpulkan data tentang tanggapan guru untuk mengukur kepraktisan buku.Data dianalisis secara deskriptif kuantitatif.Hasil dari penelitian ini menunjukkan (1) Berdasarkan pendapat ahli dan praktisi, buku bergambar dan buku panduan guru untuk kelas I Sekolah Dasar dinyatakan "valid" dengan skor ratarata sebesar 4,2 dan 4,17. (2) Berdasarkan pendapat praktisi, buku bergambar untuk kelas I Sekolah Dasar dinyatakan "praktis" dengan skor 4,0 sedangkan untuk buku guru dinyatakan "praktis" dengan skor 3.8.Berdasarkan hasil tersebut dsimpulkan bahwa penelitian ini menghasilkan buku bergambar yang valid dan praktis.
\end{abstract}

Kata Kunci : Buku Bergambar; Kepraktisan; Validitas

This study aims to develop and produce a product in the form of picture book my self theme to improve the speaking skills of grade I Elementary school students and the teacher's manual.;The research applied a design and product development research (Design \& Development) by referring to the ADDIE model (Analysis, Design, Development, Implementation, Evaluation). The data collected were validity and practicalit.The research instruments used were: validation sheets and questionnaire.Validation sheets are used to collect data about the validity of the book. Response questionnaires are used to collect data about responses.Data were analyzed descriptively quantitative.The results of this research showed that: (1) According to experts' and practitioners' opinion, picture books and teacher manual books for grade 1 elementary schools were considered "valid" with an average score of 4.2 and 4.17; (2) According to practitioner's opinion, picture books for grade 1 elementary school were considered "very practical" with the score 4.0 while teacher manual books were considered "practical" with the score 3.8; As the conclusion, this research was succeeded to produce valid and practical picture books.

Keywords : Picture Books; Practicality; Validity

\section{PENDAHULUAN}

Salah satu hal yang menunjang kehidupan yaitu pendidikan serta mengandung makna luas tergantung dari cara pandang manusia terhadap pendidikan itu sendiri. Menurut UU Nomor
20 Tahun 2003, dinyatakan pendidikan ialah suatu usaha yang disadari serta direncanakan agar tercipta proses pembelajaran serta kondisi pembelajaran yang aktif dari anak melalui pengembangan kemampuan diri guna 
memnguasai keterampilan pengendalian diri, spiritual keagamaan, akhlak yang mulia, kecerdasan, keterampilan pada Negara, bangsa, masyarakat, lingkungan serta dirinya, dan kepribadian diri.

Perkembangan teknologi dan ilmu pengetahuan dengan pesat menginginkan kemampuan yang tinggi dalam perkembangan masa. Berpikir secara kristis serta inovatif merupakan tuntutan pada era ini serta keterampilan dalam mengikuti perkembangan saat ini (Sa"ud, 2010:2). Keterampilan berbicara dibutuhkan oleh peserta didik agar komunikasi lebih intens dengan lingkungannya. Keterbatasan dalam keterampilan berbicara berperan menghambat proses komunikasi antara pemberi dan penerima pesan. Kemampuan keterampilan dalam berbicara dengan baik mampu memperjelas makna pada pesan yang diinginkan sehingga dapat diterima dengan tepat. Pemberi serta penyimak pesan diharapkan mampu menerapkan keterampilan berbicara dengan baik sehingga komunikasi berjalan dengan baik. Henry Guntur Tarigan (2008: 1) menyatakan praktik serta latihan yang maksimal mampu menguasai keterampilan berbica yang didapatkan. Pelatihan keterampilan dalam berbicara bermaksud memudahkan anak dalam memahami arti kata selama proses komunikasi. Usia dini merupakan usia emas untuk melatih keterampilan berbicara anak pada lingkungan masyarkata seperti lingkungan rumah, sekolah atau tempat lain dengan pengembangan melalui interaksi pada lingkungan lebih luas yaitu sekolah dan program khusus dalam pengembangannya. (Mudini Salamat Purba, 2009: 1).

Keterampilan berbicara ialah bagian dari keterampilan berbahasa Indonesia. Kesempatan untuk berlatih berbicara disediakan oleh lingkungan. Lingkungan yang sering mengajak mereka berbicara maka anak akan terampil berbicara (Kolnel,2019). Bahasa pengantar yang digunakan secara nasional saat ini yaitu Bahasa Indonesia dengan peran penting dalam proses berkembangnya emosioanal, sosial serta intelektual siswa dan mampu menjadi poros keberhasilan pengembangan studi pada seluruh mata pelajaran.

Peningkatan keahlian dari siswa dalam melakukan komunikasi diprioritaskan pada bidang studi Bahasa Indonesia sehingga siswa mampu mengaplikasikan salah satu keterampilan berbicara dengan baik serta tepat dan benar yang tertulis maupun lisan juga mampu meningkatkan rasa peduli dan menghormati hasil karya sastra milik Indonesia. Belajar berbahasa mampu memberikan dampak baik bagi siswa untuk mengetahui kemampuan diri sendiri, budaya yang dimiliki sendiri maupun orang lain, berpartisipasi dalam mengemukakan pemikiran gagasan serta perasaan dan kemampuan menganalisis serta imajinasi diri sendiri.

Berdasarkan Permen Pendidikan Nasional Nomor 22 Tahun 2006 dalam Standar Isi, proses belajar Bahasa Indonesia memiliki tujuan agar komunikasi mampu selaras dalam kefektifannya dilihat dari etika berkomunikasi secara tertulis ataupin dengan lisan; Bahasa Indonesia digunakan dengan bangga sebagai bahasa yang mampu mempersatu dan sebagai Bahasa bagi Negara; Bahasa Indonesia dipahami serta digunakan dengan kreatif serta tepat pada berbagai tujuan; Bahasa Indonesia digunakan guna menciptakan keterampilan intelktual serta kemampuan dalam interaksi terhadap kematangan emosional dan sosial; karya sastra dinikmati serta dimanfaatkan dalam memperhalus budi pekerti, memperluas jangkauan wawasan, kemampuan berbahasa, dan meningkatkan pengetahuan; Sastra Indonesia dihargai dan dibanggakan sebagai intelektual manusia Indonesia dan khazanah budaya.

Pemahaman paling dasar dari seseorang dalam membentuk sebuah kata atau kalimat merupakan syarat keterampilan berbicara.Kalimat dalam ukuran pendek maupun panjang memliki struktur mendasar yang berkaitan sehingga mampu memberikan arti serta makna. Komunikasi memiliki konteks yaitu pembicara berperilaku sebagai pengirim (sender), sedangkan penerima (receiver) 
berperilaku sebagai penerima berita (message). Berita terwujud dari pesan atau informasi yang dikirimkan oleh sender, dan pesan atau message ialah objek dari sebuah komunikasi. Timbal balik hadir saat berita diterima sehingga mendapatkan masukan yang berasal oleh penerima pesan serta pembelajaran dalam berbicara lebih mudah bila seluruhnya terlibat secara abktif (Iskandarwassid \& Dadang, 2016 : 240).

Proses dalam belajar Bahasa Indonesia dititikkan pada kemampuan dalam berbicara menjadi sulit sejak terbitnya Surat Edaran Kemendikbud Nomor 4 tahun 2020 tertanggal 24 Maret 2020 karena tidak ada lagi pembelajaran dengan tatap muka. Hal ini berdasarkan pengalaman peneliti sendiri yang mengalami kesulitan ketika pembelajaran bersama siswa. Pelaksanaan pembelajaran pada masa darurat Covid19 pada berbagai rentang pendidikan dari rumah, atau secara dalam jaringan (online). Tidak hanya pembelajaran akan tetapi aktivitas pedidikan lainnya seperti evaluasi, administrasi, bahkan sampai penerimaan siswa baru pun dilakukan dengan cari online.

Kebijakan ini merupakan langkah guna memutus rantai penyebaran virus Covid-19 serta menyelamatkan generasi muda dari terkena virus tersebut (Surat Edaran Mendikbud No. 4 Tahun 2020 tetang Pelaksanaan Kebijakan Pendidikan dalam Masa Darurat Penyebaran Covid19,2020). Memang kegiatan pembelajaran dalam jaringan (online) bukanlah fenomena yang baru terhadap guru di Indonesia, akan tetapi beberapa guru yang belum terlalu akrab dengannya, sebab dalam keseharian memang ratarata guru lebih dominan menggunakan pembelajaran tatap muka di banding dalam jaringan. Tentu ketidakakraban ini membuat guru, orang tua, dan siswa harus lebih beradaptasi sehingga interaksi pembelajaran tetap terjalin walau dengan jarak jauh. Selain itu penyebab kurang lancarnya siswa berbicara yaitu adanya rasa malu takut ditertawakan temannya ketika berbicara di depan kelas jika melakukan kesalahan
Pembelajaran online pada tingkat pendidikan menengah dan tinggi mungkin tidaklah terlalu sulit untuk diterapkan, mereka akan dengan mudah untuk beradaptasi, sebab dalam keseharian mereka telah hidup berdampingan dengan Smartphone. Dikatakan mereka mampu melakukannya dengan mandiri tanpa didampingi oleh orang tua. Berbeda halnya pada jenjang anak usia dini dan kelas rendah SD, anak tidaklah dapat melaksanakannya secara mandiri, mereka membutuhkan keterlibatan orang tua sebagai pendamping, dan pemandu mereka untuk ikut serta dalam pembelajaran jarak jauh.

Menurut hasil wawancara lisan yang penulis lakukan pada guru kelas satu (Guru kelas I Gugus II) di SD Negeri segugus II Kecamatan Penebel,Tabanan, pada tanggal 18 September 2020 bahwa siswa kelas satu mengalami kesulitan selama pembelajaran terutama proses keterampilan berbicara.

Serupa dengan hal tersebut berdasarkan data yang diperoleh dari Tata Usaha SD se-Gugus II, rata-rata nilai untuk keterampilan berbicara siswa kelas I SD se-gugus II masih dbawah KKM sekolah. Jika permasalahan tersebut dibiarkan begitu saja tentu banyak siswa yang tidak terampil berbicara dengan bahasa Indonesia. Mengingat bahasa Indonesia ialah bahasa persatuan, bahasa penghubung antar warga masyarakat di seluruh Indonesia. Jadi setiap warga negara Indonesia wajib untuk terampil menggunakan Bahasa Indonesia.

Berdasarkan permasalahan tersebut diatas,permasalahan timbul karena belum adanya media pembelajaran dalam meningkatkan keterampilan berbicara siswa selama proses pembelajaran sehingga dibutuhkan media pembelajaran dengan format lebih kondusif, kreatif serta inovatif sehingga mampu menciptakan keinginan siswa dalam menarik minat belajar dan mampu meningkatnya keterampilan berbicaranya.

Keberadaan buku merupakan wujud bahan ajar yang sangat penting karena dijadikan panduan oleh guru dalam mengembangkan proses belajar inovatif, serta siswa mampu mendalami 
keterampilan berbicara dengan baik.Tidak jarang terdapat permasalahan di lapangan terkait buku siswa dan guru pada perangkat pembelajaran kurikulum 2013.Diantaranya masih kurang sesuai dengan karakteristik anak (Dharma,2019). Untuk mendukung perkembangan Keterampilan Berbicara Bahasa Indonesia pada anak SD gugus II tersebut diatas mampu mempergunakan media belajar berupa buku bergambar. Nurgiatoro menyatakan (2010: 152) buku bergambar ialah buku yang diperuntukan untuk anak berupa bacaan cerita dengan tambahan visual gambar. Buku cerita bergambar menarik perhatian anak anak.Gambar pada cerita berfungsi sebagai pendukung cerita serta penghias sehingga memudahkan anak memahami isi buku (Apriliani,Radia,2020).

Ada kelebihan pada media belajar buku bergambar menurut Azizah (2016: 29) yaitu visual gambar membantu anak mengetahui serta mendalami suatu masalah pada berbagai bidang tanpa melihat rentang usia dengan harga terjangkau dan praktis dalam penyampaiannya. Buku bergambar berikisikan gambar ilustrasi serta menggunakan tema tertentu. Gambar dalam media buku bergambar bertujuan guna memberikan gambar visual atau imajinasi pada anak guna anak menyerap serta medalami lebih cepat dan baik mengenai materi pada buku dikarenakan anak memiliki daya imajinasi, daya berfantasi, serta kemampuan bermain. Anak mampu menciptakan imajinasi dalam pengembangannya dengan bantuan gambaran ilustrasi.

$$
\text { Pengembangan }
$$

media pembelajaran garmbar bertujuan agar siswa memiliki kemampuan interpretasi isi cerita berdasarkan kemampuan imajinasi sehingga siswa mampu menceritakan hal dalam cerita yang telah dibacanya seperti isi cerita, pengamatan dengan Bahasa yang baik dan memiliki makna. Gambar cerita diusahakan sebagai alat bantu agar siswa tidak mengalami masa jenuh dan terkesan monoton sehingga anak memiliki keinginan untuk belajar lebih dalam mempergunakan kemampuan audionya secara maksimal pada saat memperhatikan guru. Anak yang telah menperhatikan cerita guru, kemampuan imajinasi yang anak miliki berdampingan sesuai dengan alur serta tokoh pada cerita guru dan anak mampu memiliki keterampilan dalam mengungkapkan kembali serta menerapkan hal positif dari alur dan tokoh pada cerita.

Keahlian yang dimiliki anak dalam mengungkapkan kembali hal yang terdapat pada cerita ialah keterampilan dasar yang harus dimiliki. Buku bergambar bisa digunakan sebagai pembelajaran agar anak memperoleh bahasa Indonesia dengan baik. Buku bergambar dasarnya adalah salah satu media efektif pada pembelajaran terutama diterapkan pada siswa kelas rendah dalam meningkatkan pemerolehan bahasa anak.

Berdasarkan pertimbanganpertimbangan tersebut maka penulis berinisiatif dalam mengembangkan bahan ajar dalam bentuk buku, yang mampu memberikan kenaikan kemampuan berbicara siswa.

Melalui penelitian yang berjudul "Pengembangan Buku Bergambar pada Tema Diriku Untuk Meningkatkan Keterampilan Berbicara Siswa Kelas I SD Gugus II Kecamatan Penebel,Tabanan" diharapkan akan mampu dihasilkan Buku Bergambar Tema Diriku untuk Kelas I Sekolah Dasar yang valid, dan praktis.

\section{METODE}

Penelitian ini menggunakan metode penelitian dan pengembangan. Produk yang dihasilkan dengan menggunakan penelitian ialah buku bergambar untuk meningkatkan ketrampilan berbicara siswa kelas I SD. Borg and Gall (Purnama, 2013), menyatakan bahwa model penelitian dan pengembangan adalah "a process used develop and validate educational product", yang berarti bahwa penelitian pengembangan merupakan suatu usaha yang dilakukan untuk mengembangkan dan menghasilkan produk pembelajaran serta menguji (memvalidasi) produk tersebut.

Penelitian ini merujuk pada model ADDIE yang dikembangkan Reiser dan Mollenda sekitar tahun 1990an. Tahapan 
pengembangan dengan model ADDIE meliputi:analize, design, development, implementation,dan evaluation. Subyek dalam penelitian ini yaitu: 1) Ahli, untuk memvalidasi kelayakan isi, kelayakan kebahasaan, kelayakan sajian, dan kelayakan kegrafikan buku teks yang dikembangkan. 2) Guru kelas I SD, memberikan penilaian terhadap buku berganmbar Tema I Diriku mengenai kelayakan buku yang meliputi kelayakan isi, kelayakan kebahasaan, kelayakan sajian, dan kelayakan kegrafikan serta kepraktisan buku.

Instrumen penelitian yang

digunakan yaitu: lembar validasi dan angket.Lembar validasi dipakai untuk mengumpulkan data tentang validitas dan buku.Validitas buku yang dimaksud yaitu mencakup kelayakan isi, kelayakan kebahasaan,kelayakan sajian dan kelayakan kegrafikan.Lembar validasi yang dikembangkan terdiri atas pernyataan-pernyataan positif, dengan 5 alternatif jawaban, yaitu sangat baik (SB), baik (B), cukup baik (C), kurang baik (KB), dan sangat kurang baik (SKB).Lembar validasi dilengkapi dengan rubrik, untuk memudahkan validator dalam memberi penilaian.Lembar validasi ini diisi oleh 2 orang ahli dan 1 orang praktisi.Hasil validasi dipakai untuk menentukan apakah rancangan buku sudah dapat diuji coba secara terbatas di lapangan.
Angket respon guru digunakan untuk mengumpulkan data tentang tanggapan guru setelah menggunakan buku dalam pembelajaran.Dalam penelitian ini,angket respon guru terdiri atas beberapa pernyataan positif, dengan 5 alternatif jawaban, yaitu sangat setuju (SS), setuju (S), cukup setuju (CS), kurang setuju (KS), dan sangat kurang setuju (SKS). Data yang dikumpulkan dari angket respon guru ini selanjutnya dijadikan sebagai bahan untuk perbaikan dalam uji coba berikutnya.Data kualitatif yang berasal dari tanggapan dan saran dari ahli dan praktisi (guru)dirangkum dan disimpulkan untuk selanjutnya digunakan sebagai bahan perbaikan rancangan buku sebelum diuji-cobakan.Sementara data kualitatif yang berasal dari pengisian lembar validasi oleh ahli dan praktisi, diubah menjadi data kuantitatif.Data kuantitatif selanjutnya dianalisis menurut aspek kelayakan buku yang selanjutnya dihitung rata-rata skor dari setiap aspek.

Data yang telah terkumpul selanjutnya dianalisis dengan deskriptif kuantitatif.

\section{HASIL DAN PEMBAHASAN}

Penelitian ini difokuskan untuk mengembangkan buku bergambar pada Tema Diriku untuk Meningkatkan Keterampilan Berbicara Siswa Kelas I SD. Data hasil validitas buku siswa dapat dilihat pada Tabel 1 berikut.

Tabel 1. Hasil Analisis Hasil Uji Validitas Buku Siswa

\begin{tabular}{llcccc}
\hline No & \multicolumn{1}{c}{ Komponen } & Ahli Media & Ahli Materi & Ahli Desain & Praktisi \\
\hline 1. & Kelayakan Kegrafikan & 108 & 116 & 127 & 114 \\
2. & Kelayakan Bahasa & 60 & 66 & 64 & 62 \\
3. & Kelayakan Isi & 36 & 38 & 38 & 36 \\
4. & Kelayakan Penyajian & 32 & 34 & 37 & 32 \\
& Jumlah & 236 & 254 & 266 & 244 \\
& Rata -rata Skor & 4,00 & 4,30 & 4,50 & 4,13 \\
& Rata -rata & \multicolumn{3}{c}{4,2} \\
& Kategori & \multicolumn{3}{c}{ Valid } \\
\hline
\end{tabular}

Berdasarkan data Tabel 1 menunjukkan bahwa validitas buku teks yang dikembangkan dinyatakan "valid" dengan skor rata-rata "4,2". Hasil uji validitas buku panduan guru disajikan pada Tabel 2 berikut. 
Tabel 2. Data Analisis Hasil Uji Validitas Buku Panduan Guru

\begin{tabular}{lllll}
\hline No & Komponen & Ahli Media & Ahli Materi & Praktisi \\
\hline 1. & Kelayakan Kegrafikan & 64 & 69 & 70 \\
2. & Kelayakan Bahasa & 44 & 45 & 48 \\
3. Kelayakan Isi & 16 & 18 & 18 \\
4. & Kelayakan Penyajian & 32 & 32 & 32 \\
& Jumlah & 156 & 164 & 168 \\
& Skor & 4,00 & 4,20 & 4,30 \\
& Rata -rata & 4,17 & \\
& Kategori & Valid & \\
\hline
\end{tabular}

Berdasarkan data Tabel 2 menunjukkan bahwa validitas buku Panduan guru yang dikembangkan dinyatakan "valid" dengan skor rata-rata 4,17 .
Untuk menguji kepraktisan buku bergambar dan buku panduan guru,maka guru diberikan angket respon terhadap kedua buku tersebut.Hasil analisis angket respon guru disajikan pada Tabel 3 berikut

Tabel 4. Hasil Analisis Angket Respon Guru terhadap Buku Guru

\begin{tabular}{|c|c|c|}
\hline No & Komponen & Skor \\
\hline 1 & Ketertarikan & 54 \\
\hline 2 & Penyajian Materi & 36 \\
\hline 3 & Bahasa & 24 \\
\hline & Jumlah & 38 \\
\hline & Rata-rata & 3,8 \\
\hline & Kategori & Praktis \\
\hline
\end{tabular}

Tabel 4.menunjukkan bahwa buku panduan guru yang dikembangkan dinyatakan "praktis". Buku bergambar yang sudah dinyatakan praktis tidak diuji cobakan lagi ke tahap 2 karena sudah memenuhi kriteria kepraktisan yang ditentukan..

Untuk menghasilkan buku teks yang valid dan praktis penelitian ini mengadopsi model ADDIE.Model pengembangan ini terdiri atas 5 tahap, yaitu analisis, perancangan, pengembangan, implementasi, dan evaluasi. Kegiatan yang dilakukan pada kelima tahap tersebut dapat dijelaskan sebagai berikut.

Pertama, Tahap analisis (analyze). Pada tahap ini dilakukan analisis terhadap kompetensi dasar, yang mencakup analisis kompetensi dasar yang memuat keterampilan berbicara. Pada tahap ini juga dikumpulkan data mengenai kriteria buku yang valid, praktis, dan efektif. Datadata yang terkumpul berguna untuk menentukan rancangan buku dan instrumen yang akan dibuat.

Kedua, Tahap perancangan (design). Pada tahap ini rancangan buku dan instrumen dibuat sesuai kebutuhan. Rancangan instrumen selanjutnya divalidasi oleh 3 orang dosen ahli. Rancangan buku dibuat dengan mengacu pada Permendikbud Nomor 8 Tahun 2016. Ketiga, Tahap pengembangan (development). Pada tahap ini rancangan buku dikembangkan menjadi draf buku. Draf buku selanjutnya divalidasi oleh 3 orang ahli dan 1 orang praktisi, dengan menggunakan instrumen berupa lembar validasi yang telah dibuat dan divalidasi pada tahap sebelumnya. Draf buku yang telah valid selanjutnya diuji cobakan secara terbatas di lapangan. Terdapat beberapa catatan yang diberikan oleh ahli yaitu agar memperhatikan kaidah kebahasaan. Hal ini bertujuan agar teks bacaan pada buku sesuai dengan Ejaan bahasa Indonesia.Catatan yang lain yaitu isi buku kurang interaktif.Masih terkesan pasif sehingga belum menunutut siswa untuk berpikir dan mengembangkan keterampilan berbicaranya. Berikut adalah salah satu bagian dari draf buku sebelum dan sesudah direvisi yang diberikan masukan oleh ahli materi. 
Sebelum revisi

Desak menyebutkan nama teman barunya. Nama temannya adalah Wati, Desak, Arif dan Edi.

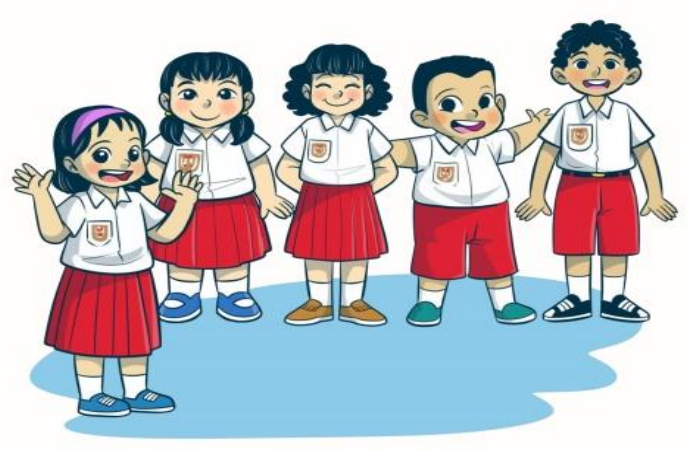

Desak bangun pagi pukul 06.00. Kemudia ia mandi dan memakai seragam.Desak lalu berpamitan dengan kedua orang tuanya

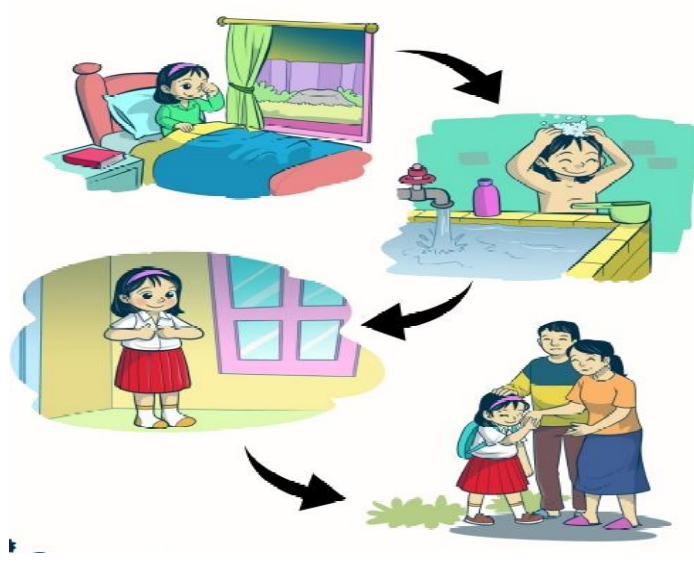

Setelah revisi

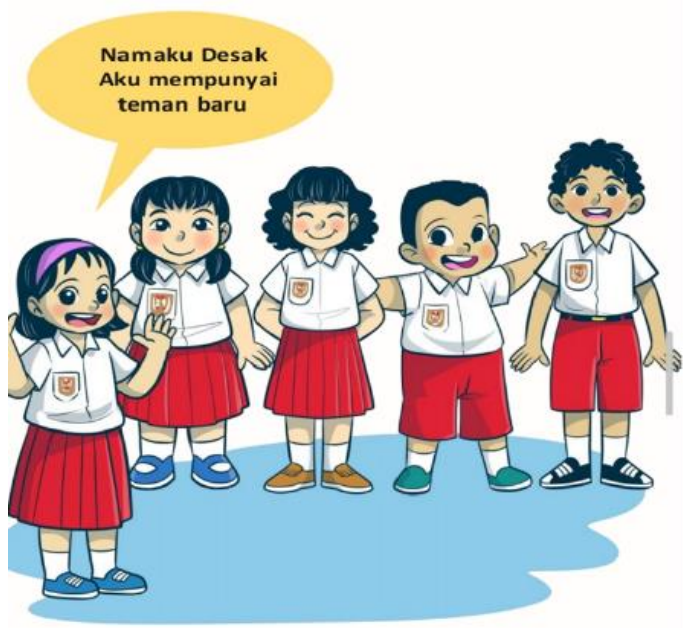

Sudahkah kamu memiliki teman baru? Siapa nama teman barumu?

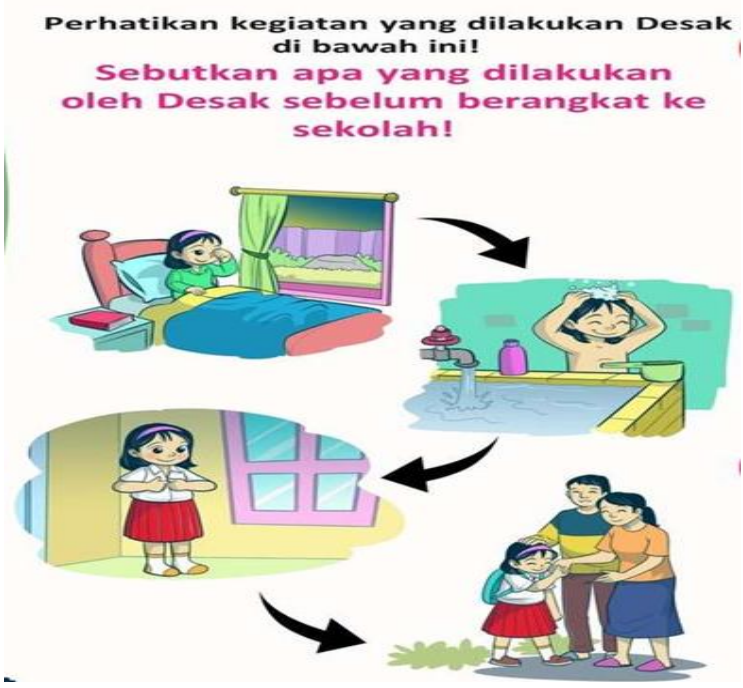

Gambar 1. Hasil revisi berdasarkan saran ahli

dilakukan

Berdasarkan saran ahli, kemudian dinyatakan layak dari segi penyajian apabila (1) materi disajikan secara menarik; (2) ilustrasi yang disajikan dapat memperjelas materi; (3) ilustrasi tidak mengandung unsur SARA, kekerasan, pornografi, dan paham-paham lain yang dapat merusak persatuan bangsa; (4) materi dapat merangsang untuk berpikir kritis, kreatif, dan inovatif; (5) mengandung wawasan yang kontekstual; (6) materi dapat menumbuhkan keingintahuan pembaca. Terakhir, buku dinyatakan layak dari segi kegrafikan apabila (1) ukuran buku sesuai dengan tahap perkembangan peserta didik; (2) tata letaknya harmonis; (3) warnanya harmonis dan dapat memperjelas fungsi; (4) jenis dan ukuran huruf sesuai dengan tahap perkembangan peserta didik.(Depdiknas 2008)

Validitas dan kepraktisan, diukur dengan menggunakan instrument 
diantaranya lembar validasi, angket respon guru.

Pengujian instrumen dilakukan sebelum penelitian,diuji terlebih dahulu oleh 2 orang dosen ahli agar lebih valid.Validitas buku diuji dengan menggunakan lembar validasi.Butir instrumen validasi yang digunakan meliputi aspek kelayakan kegrafikan, kelayakan bahasa, kelayakan isi, dan kelayakan penyajian.(Depdiknas 2008).

Nieveen (1999) dalam Sutariani 2019 menyatakan bahwa kevalidan produk pada pembelajaran saat pengembangan produk tersebut sesuai dengan pengetahuan masa kini serta komponen secara kontinu berkaitan satu sama lain. Selarasa dengan hal tersebut, Permendikbud Nomor 8 Tahun 2016 menyatakan, buku dikatakan valid bila memenuhi 4 kriteria, yaitu kelayakan kebahasaan, kelayakan isi, kelayakan kegrafikan, dan kelayakan penyajian. Buku dinyatakan layak dari segi materi bila (1) materi yang disajikan akurat, mutakhir, serta menggunakan sumber yang benar secara teoritik dan empirik; (2) mendorong timbulnya kemandirian dan inovasi; (3) mampu memotivasi; (4) mampu menjaga persatuan dan kesatuan bangsa. Buku dinyatakan layak dari segi kebahasaan bila (1) bahasa yang digunakan lugas, tepat, jelas, serta sesuai dengan tahap perkembangan peserta didik; (2) ilustrasi materi dapat dipahami dengan mudah; (3) bahasa yang digunakan komunikatif dan informatif; (4) menarik dan tidak provokatif.

Lebih lanjut dijelaskan bahwa buku dinyatakan layak dari segi penyajian apabila (1) materi disajikan secara menarik; (2) ilustrasi yang disajikan dapat memperjelas materi; (3) ilustrasi tidak mengandung unsur SARA, kekerasan, pornografi, dan paham-paham lain yang dapat merusak persatuan bangsa; (4) materi dapat merangsang untuk berpikir kritis, kreatif, dan inovatif; (5) mengandung wawasan yang kontekstual; (6) materi dapat menumbuhkan keingintahuan pembaca. Terakhir, buku dinyatakan layak dari segi kegrafikan apabila (1) ukuran buku sesuai dengan tahap perkembangan peserta didik; (2) tata letaknya harmonis; (3) warnanya harmonis dan dapat memperjelas fungsi; (4) jenis dan ukuran huruf sesuai dengan tahap perkembangan peserta didik (Depdiknas 2008).

Berdasarkan pendapat 3 orang dosen ahli dan 1 orang praktisi (guru), buku bergambar Tema Diriku Untuk Meningkatkan Keterampilan Berbicara untuk kelas I SD yang dikembangkan dalam penelitian ini, dinyatakan "valid" dengan skor rata-rata 4,2.

Nieveen (1999) menyatakan tingginya kualitas suatu kepraktisan menjadi karakteristik dari sebuah produk pendiidkan bila guru serta ahli bidang studi mampu memberikan pertimbangan mengenai produk tersebut sehingga mampu untuk dipergunakan dan dalam kenyataannya ditunjukkan kemudahan yang diperuntukkan untuk pendidik serta peserta didik selama mempergunakan produk itu. Hal ini membuktikan adanya sikap konsisten antara penrtimbangan dengan harapan ataupun operasional dengan harapan. Oleh karena itu, di akhir praktisi diminta untuk memberikan penilaian terhadap buku dengan menggunakan angket respon.

Berdasarkan pendapat praktisi, buku bergambar yang dikembangkan dalam penelitian ini tergolong "Praktis"dengan skor 4.0.Sementara itu buku panduan guru dengan skor kepraktisan 3,8.

Nieveen dalam (Sutariani 2019) menyatakan bahwa keefektifan produk pendidikan berhasil bila tujuan dari pembelajaran tercapai menggunakan produk yang dikembangkan tersebut. Dalam Permendikbud Nomor 23 tahun 2016, dijabarkan bahwa ketercapaian tujuan pembelajaran dapat diketahui dengan mengadakan penilaian. Sejalan dengan hal tersebut penelitian ini seharusnya diikuti dengan uji efektivitas dalam menilai keberhasilan siswa selama proses pembelajaran menggunakan produk buku bergambar yang dikembangkan.Akan tetapi dikarenakan saat penelitian ini berlangsung situasi pandemi Covid-19 sehingga kegiatan tatap muka dalam pembelajaran di sekolah tidak bisa terselenggara (Surat Edaran Kementerian Pendidikan dan Kebudayaan Nomor 4 tahun 2020 tertanggal 24 Maret 2020) untuk 
meminimalisasi penyebaran Covid-19. Oleh karena itu uji efektivitas terhadap buku bergambar belum bisa dilaksanakan dalam penelitian ini.

\section{PENUTUP}

Berdasarkan hasil penelitian dan pembahasan yang telah dikemukakan sebelumnya, maka dapat disimpulkan beberapa hal sebagai berikut.

(1) Berdasarkan pendapat ahli dan praktisi, buku bergambar dan buku panduan guru untuk kelas I Sekolah Dasar dinyatakan "valid" dengan skor rata-rata sebesar 4,2 dan 4,17. (2) Berdasarkan pendapat praktisi, buku bergambar untuk kelas I Sekolah Dasar dinyatakan "praktis" dengan skor 4,0 sedangkan untuk buku guru dinyatakan "praktis" dengan skor 3,8 Penelitian dan pengembangan buku bergambar ini masih terbatas.Uji efektivitas buku belum bisa dilakukan karena situasi pandemi covid 19 sehingga tidak ada kegiatan tatap muka dengan siswa. Untuk selanjutnya disarankan kepada peneliti lain agar dapat dilakukan penelitian lanjutan hingga tahap implementasi di lingkup yang lebih luas.Tahapan implementasi sangatlah terbatas dalam penelitian serta pengembangan buku guru yang mana terbatas pada lingkup sehingga penelitian lanjutan dapat dilaksanakan pada lingkup yang lebih luas.

\section{DAFTAR RUJUKAN}

$\begin{array}{lr}\text { Apriliani Siwi Prawestri, dan } & \text { Elvira } \\ \text { Hoesein Radia. } & 2020 . \\ \text { Pengembangan } & \text { Media } \\ \text { Pembelajaran Buku } & \text { Cerita } \\ \text { Bergambar Untuk Meningkatkan } \\ \text { Minat Membaca Siswa Sekolah } \\ \text { Dasar.Jurnal Basicedu Vo.4 N0.4 } \\ \text { SSN 2580-3735. }\end{array}$

Arifin, Zaenal.2009. Evaluasi Pendidikan Bandung: PT Remaja Rosdakarya.

Artiono, O. P. 2015. "Pengembangan Buku Teks Matematika dengan Pendekatan Konstruktivisme untuk Siswa Kelas V SDIT Internasional Luqman AlHakim Yogyakarta Kelas Bilingual'.
Azizah, Nur. 2016. "Pengembangan Media Pembelajaran Buku Bergambar Pada Mata Pelajaran Bahasa Indonesia Materi Menulis Puisi Kelas III Madrasah Intidaiyah Darussalam Tajinan Malang". Skripsi. Malang: UIN Malang

Dharma Aditya.2019.Pengembangan Buku Cerita Anak Bergambar Denga Insersi Budaya Lokal Bali Terhadap Minta Baca Dan Sikap Siswa Kelas $\checkmark$ SD.Journal For Leasson And Learning Studies.Vol.2 No.1

Depdiknas.2008.

Panduan Pengembangan Bahan Ajar. Jakarta: Kementerian Pendidikan dan Kebudayaan Direktorat Jendral Pendidikan Dasar Direktorat Pembinaat Sekolah Dasar.

Iskandarwassid \& Dadang Sunendar. (2011). Strategi Pembelajaran Bahasa. Bandung : PT. Remaja Rosdakarya

Kolnel Oktaria Mbeni Haba. 2019. Penerapan Metode Bermain Peran Untuk Meningkatkan Keterampilan Berbicara Siswa Kelas I Pada Pelajaran Bahasa Indonesia Sekolah Dasar.Jurnal IImiah Polyglot Vol.15

Nahgiyah,Stefanus

C.Relmasira.2019. Upaya

Peningkatan Keterampilan Berbicara dan Hasil Belajar Melalui Model Pembelajaran Cooperative Learning Tipe Jigsaw.Journal of Education action Research.Vol.2,Number 3

Nurgiyantoro, Burhan. (2012). Penilaian Pembelajaran Bahasa Berbasis Kompetensi. Yogyakarta: BPFEYogyakarta.
Purba,
Mudini
Salamat.
2009. Pembelajaran
Berbicara.Jakarta:Pusat
Pengembangan dan Pemberdayaan
Pendidik dan Tenaga Kependidikan
Bahasa Direktorat Jenderal
Peningkatan Mutu Pendidik dan
Tenaga Kependidikan Departemen
Pendidikan Nasional. 
Purnama, S. (2013). Produk Pembelajaran Bahasa Arab. Literasi Vol 4 no 1, 1932.

Sa"ud, Udin Saefudin. 2010. Inovasi Pendidikan. Bandung: Alfabeta.

Sutariani, Desak Putu.2019. Pengembangan Buku Teks Matematika Kurikulum 2013 Bermuatan Keterampilan Abad Ke21 (4c) Untuk Kelas Vi SekolahDasar.Singaraja.Universitas Pendidikan Ganesha.

Tarigan, Henry Guntur. 2008. Berbicara sebagi Suatu Keterampilan Berbahasa. Bandung: Angkasa 